\title{
Protonated Ethanol and Its Neutral Counterparts
}

\author{
Chrysostomos Wesdemiotis \\ Department of Chemistry, The University of Akron, Akron, Ohio, USA
}

\author{
Aberra Fura and Fred W. McLafferty \\ Baker Chemistry Laboratory, Department of Chemistry, Cornel] University, Ithaca, New York, USA
}

Collisionally activated dissociation and neutralization-reionization experiments reveal that protonation of ethanol leads to two distinct isomers, the classical ion $\mathrm{CH}_{3} \mathrm{CH}_{2} \mathrm{OH}_{2}^{+}$and the proton-bound complex $\mathrm{C}_{2} \mathrm{H}_{4} \ldots \mathrm{H}^{+} \ldots \mathrm{OH}_{2}$. The neutral counterpart of the latter is unstable, whereas that of the former can be produced in a bound state if the $\mathrm{CH}_{3} \mathrm{CH}_{2} \mathrm{OH}_{2}^{+}$ precursor ion is formed under low ion source pressure conditions and, thus, with higher internal energies. This suggests that there are substantial differences in the geometries of $\mathrm{CH}_{3} \mathrm{CH}_{2} \mathrm{OH}_{2}^{+}$and the hypervalent $\mathrm{CH}_{3} \mathrm{CH}_{2} \mathrm{OH}_{2}$. This provides only a partial explanation for unusual isotope effects; $\mathrm{C}_{2} \mathrm{H}_{5} \mathrm{OD}_{2} \cdot \mathrm{CH}_{3} \mathrm{CD}_{2} \mathrm{OD}_{2} \cdot$, and $\mathrm{CD}_{3} \mathrm{CH}_{2} \mathrm{OD}_{2} \cdot$ are substantially more stable than $\mathrm{C}_{2} \mathrm{D}_{5} \mathrm{OD}_{2} \cdot$ and $\mathrm{C}_{2} \mathrm{H}_{5} \mathrm{OH}_{2} \cdot$. (f Am Soc Mass Spectrom 1991, $2,459-463)$

\section{$\mathrm{T}$} he unimolecular reactions of protonated ethanol have been the subject of several investigations [1-5]. Bowers and co-workers [4b] observed that the intensities of the fragments formed upon collisionally activated dissociation (CAD) [6] vary with ion source pressure, indicating dependence on internal energy or angular momentum. Extensive labeling experiments by Harrison [3] and by Bowers and $\mathrm{co}^{-}$ workers [4a] showed further that the major dissociations into $\mathrm{C}_{2} \mathrm{H}_{5}^{+}+\mathrm{H}_{2} \mathrm{O}$ and $\mathrm{H}_{3} \mathrm{O}^{+}+\mathrm{C}_{2} \mathrm{H}_{4}$ are preceded by substantial $\mathrm{H}$ scrambling between the hydrogens of the carbons and oxygen. Although $\mathrm{CH}_{3} \mathrm{CH}_{2} \mathrm{OH}_{2}^{+}\left(1^{+}\right)$isomerization to protonated dimethyl ether has been excluded by these groups, rearrangement to other stable $\mathrm{C}_{2} \mathrm{H}_{7} \mathrm{O}^{+}$structures has not been considered. The scrambling has been assumed to occur in the dissociation process, via a $\mathrm{C}_{2} \mathrm{H}_{4} \ldots{ }^{+} \mathrm{OH}_{3}$ [4a] or $\mathrm{C}_{2} \mathrm{H}_{4} \ldots \mathrm{H}^{+} \ldots \mathrm{OH}_{2}$ [3] ion-molecule complex that is sampled several times before fragmentation. This claim was substantiated by showing that the $\mathrm{CAD}$ spectra of $\mathrm{CH}_{3} \mathrm{CH}_{2} \mathrm{OH}_{2}^{+}$and of $\mathrm{C}_{2} \mathrm{H}_{7} \mathrm{O}^{+}$generated in the ion source by association of $\mathrm{C}_{2} \mathrm{H}_{4}$ and $\mathrm{OH}_{3}^{+}$are very similar [4a]. Similarly, the reaction of $\mathrm{OD}_{3}^{+}$with $\mathrm{C}_{2} \mathrm{H}_{4}$ in a quadrupole collision cell produced significant quantities of $\mathrm{C}_{2} \mathrm{H}_{3} \mathrm{D}_{2}^{1}$, $\mathrm{OHD}_{2}^{+}, \mathrm{OH}_{2} \mathrm{D}^{+}$, and $\mathrm{OH}_{3}^{+}$, indicating that a complex between $\mathrm{OD}_{3}^{+}$and $\mathrm{C}_{2} \mathrm{H}_{4}$ is formed "which survives sufficiently long for hydrogen interchange to occur"

Presented at the Thirty-Eighth ASMS Conference on Mass Spec trometry and Allied Topics, Tucson, June 1990.

Address reprint requests to Chrysostomos Wesdemiotis, Depart ment of Chemistry, The University of Akrort, Akron, OH 44325.
[3]. Neither group suggested that such a complex could represent a stable, bound $\mathrm{C}_{2} \mathrm{H}_{7} \mathrm{O}^{+}$isomer. In the present study we provide evidence from CAD and neutralization-reionization mass spectrometry (NRMS) experiments [7] that the proton-bound complex $\mathrm{C}_{2} \mathrm{H}_{4} \ldots \mathrm{H}^{+} \ldots \mathrm{OH}_{2}\left(2^{+}\right)$is also formed upon the protonation of ethanol and survives long enough (> $10^{-5} \mathrm{~s}$ ) to yield characteristic mass spectra. High-level molecular orbital calculations by Radom and coworkers [8a] and by Bouchoux and Hoppilliard [8b], reported since the completion of this study, predict that $2^{+}$represents an energy minimum lying 53 [8a] or $69[8 \mathrm{~b}] \mathrm{kJ} \mathrm{mol}^{-1}$ above $1^{+}$and separated from it by a barrier of 42 or $51 \mathrm{~kJ} \mathrm{~mol}^{-1}$.

The counterneutral of protonated ethanol, the hypervalent $\mathrm{CH}_{3} \mathrm{CH}_{2} \mathrm{OH}_{2} \cdot$, has not yet been identified and is also characterized in this study. Porter and co-workers [9] found that the similar but smaller hypervalent homologs $\mathrm{CH}_{3} \mathrm{OH}_{2} \cdot$ and $\mathrm{OH}_{3} \cdot$ are not stable (lifetime $<10^{-9} \mathrm{~s}$ ), but that the perdeuterated species are stable and experimentally observable (lifetime $\sim 10^{-6} \mathrm{~s}$ ). Even more unusual isotope effects have been observed; ${ }^{18} \mathrm{OD}_{3} \cdot$ is reported to be far less stable than ${ }^{16} \mathrm{OD}_{3}$. [9]. A recent NR study by Holmes and Sirois $[10]$ of protonated dimethyl ether finds that the isomeric $\mathrm{CH}_{3} \mathrm{OH}_{2} \mathrm{CH}_{3} \cdot$ can be produced as a bound neutral.

\section{Experimental}

The experiments were performed with the Cornell tandem double-focusing mass spectrometer (EB-EB) 
described in detail elsewhere [11]. For NR spectra, 10-keV precursor ions are mass-selected by MS-I (EB) and enter the neutralization collision cell (Cls-I) where they undergo charge-exchange collisions with $\mathrm{Hg}$ vapor. Any remaining ions are removed by electrostatic deflection and the resulting neutral beam enters the reionization cell $\left(\mathrm{Cl}_{\text {s-II) }}\right.$ where it is collisionally reionized by $\mathrm{O}_{2}$ targets into cations. The resulting ions are mass-analyzed through MS- $\Pi$ (E-II). For CAD spectra, the precursor ions undergo dissociating collisions with $\mathrm{O}_{2}(70 \%$ transmittance) targets in Cls-II. The NR $\mathrm{Hg} / \mathrm{O}_{2}$ spectra [12] employed transmittance values of $90 \%$ for $\mathrm{Hg}$ and $70 \%$ for $\mathrm{O}_{2}$, corresponding to singlecollision conditions [13]. Neutral beam abundances are measured at a retractable in-line detector after Cls-II.

The parent ions $\mathrm{C}_{2} \mathrm{H}_{5} \mathrm{OH}_{2}^{+}, \mathrm{C}_{2} \mathrm{H}_{5} \mathrm{OD}_{2}^{+}$, $\mathrm{CH}_{3} \mathrm{CD}_{2} \mathrm{OH}_{2}^{+}, \mathrm{CD}_{3} \mathrm{CH}_{2} \mathrm{OH}_{2}^{+}$, and $\mathrm{C}_{2} \mathrm{D}_{5} \mathrm{OD}_{2}^{+}$were produced by self-chemical ionization under high or low ion source pressure conditions. $\mathrm{CH}_{3} \mathrm{CD}_{2} \mathrm{OD}_{2}^{+}$and $\mathrm{CD}_{3} \mathrm{CH}_{2} \mathrm{OD}_{2}^{+}$were generated in the ion source by mixing $\mathrm{D}_{2} \mathrm{O}$ with $\mathrm{CH}_{3} \mathrm{CD}_{2} \mathrm{OH}$ and $\mathrm{CD}_{3} \mathrm{CH}_{2} \mathrm{OH}$, respectively, The $\left[\mathrm{MH}^{+}\right]:\left[\mathrm{M}^{+},\right]$ratio in the ion source was $\geq 6$ under high and $\leq 0.5$ under low ion source pressure. The contamination extent of $\mathrm{NR} \mathrm{MH}^{+}$(or $\mathrm{MD}^{+}$) with the ${ }^{13} \mathrm{C}$ (or ${ }^{18} \mathrm{O}$ ) isotope of $\mathrm{M}^{+}$was determined from $\left[\mathrm{MH}^{+}\right]:\left[\mathrm{M}^{+} \cdot\right]$ as well as the NR efficiencies of $\mathrm{MH}^{+}$(or $\mathrm{MD}^{+}$) and $\mathrm{M}^{+}$. measured under identical experimental settings [12]. All samples were obtained commercially and used without further purification.

\section{Results and Discussion}

\section{$\mathrm{C}_{2} \mathrm{H}_{7} \mathrm{O}^{\prime}$ Ions}

High ion source pressure. $\mathrm{C}_{2} \mathrm{H}_{5} \mathrm{OH}_{2}^{+}$parent ions produced under thermalizing (high ion source pressure) conditions lead upon $\mathrm{CAD}$ to two types of fragmentation processes (Figure 1, left column, and Table 1 for thermochemical values): (1) reactions preceded by substantial $\mathrm{H}$ exchange such as the formation of $\mathrm{H}_{3} \mathrm{O}^{+}$ and $\mathrm{C}_{2} \mathrm{H}_{5}^{+}$by loss of $\mathrm{C}_{2} \mathrm{H}_{4}$ and $\mathrm{H}_{2} \mathrm{O}$, respectively; and (2) climinations accompanicd by no appreciable scrambling such as the specific losses of $\mathrm{H} \cdot$ (methylene or methyl hydrogen) and $\mathrm{CH}_{4}$ (methyl group and one of the hydroxylic $\mathrm{H}$ atoms). These results can best be rationalized by assuming the presence of two distinct $\mathrm{C}_{2} \mathrm{H}_{5} \mathrm{OH}_{2}^{+}$isomers, namely, the initially formed classical ion $1^{+}$and the proton-bound complex $2^{+}$to which $1^{+}$can partly isomerize after its formation (Scheme I). $\mathrm{CH}_{2} \mathrm{OH}^{+}$and $\cdot \mathrm{C}_{2} \mathrm{H}_{4} \mathrm{OH}_{2}^{+}$are then formed from $1^{+}$via specific $1,2 \mathrm{CH}_{4}$ and $\mathrm{H}$. eliminations, respectively, whereas $\mathrm{C}_{2} \mathrm{H}_{5}^{+}$and $\mathrm{H}_{3} \mathrm{O}^{+}$originate from $2^{+}$in which extensive $\mathrm{H}$ exchange can take place prior to dissociation. The $2^{+}$ions formed $\mathrm{di}^{-}$ rectly by association of $\mathrm{C}_{2} \mathrm{H}_{4}$ with ${ }^{+} \mathrm{OH}_{3}$ should lose substantially less $\mathrm{CH}_{4}$ and $\mathrm{H} \cdot$, as indeed observed by Bowers and co-workers [4a]. Because of the larger

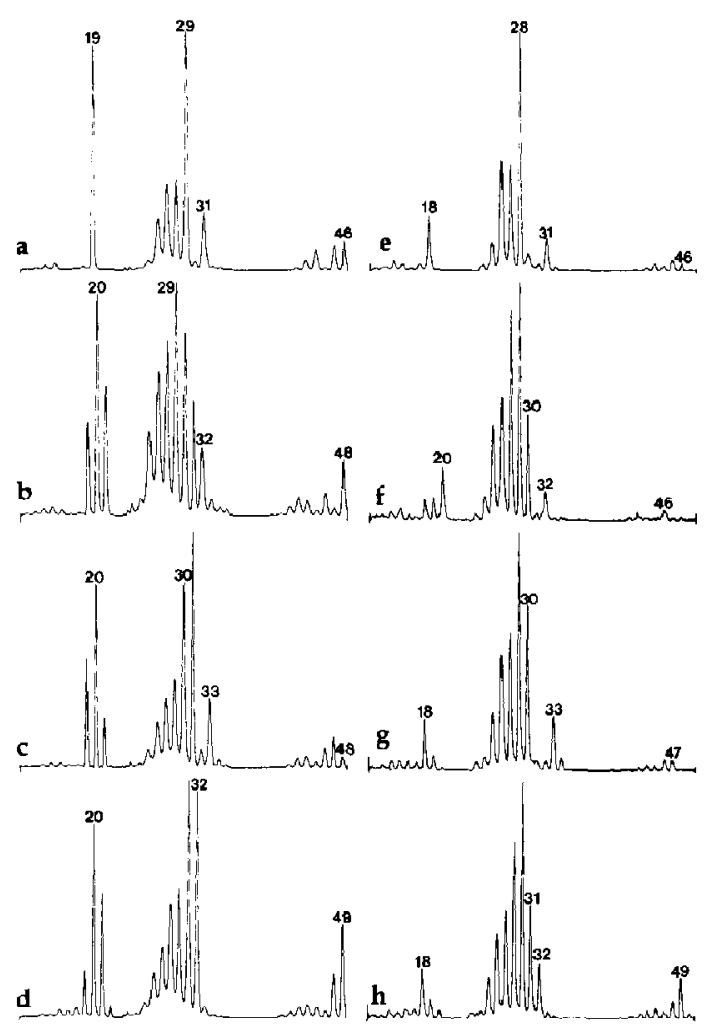

Figure 1. (a-d) CAD and (e-h) NR spectra of (a,e) $\mathrm{CH}_{3} \mathrm{CH}_{2} \mathrm{OH}_{2}^{+}$, (b, f) $\mathrm{CH}_{3} \mathrm{CH}_{2} \mathrm{OD}_{2}^{+}$, (c, g) $\mathrm{CH}_{3} \mathrm{CD}_{2} \mathrm{OH}_{2}^{+}$, and (d, h) $\mathrm{CD}_{3} \mathrm{CH}_{2} \mathrm{OH}_{2}^{+}$under high ion source pressure conditions.

proton affinity of water in comparison to that of ethylene (697 versus $680 \mathrm{~kJ} \mathrm{~mol}^{-1}$ [14]), $2^{+}$should resemble more a complex of ethylene plus hydronium $\left(\mathrm{C}_{2} \mathrm{H}_{4} \ldots \mathrm{OH}_{3}^{+}\right)$than a complex of ethylium plus water $\left(\mathrm{C}_{2} \mathrm{H}_{5}^{+} \ldots \mathrm{OH}_{2}\right)$.

The isomerization to $2^{+}$indicates the initial formation of energetic $1^{+}$ions. The self-protonation $\mathrm{C}_{2} \mathrm{H}_{5} \mathrm{OH}^{+} \cdot+\mathrm{C}_{2} \mathrm{H}_{5} \mathrm{OH} \rightarrow \mathrm{C}_{2} \mathrm{H}_{5} \mathrm{OH}_{2}^{+}+\mathrm{C}_{2} \mathrm{H}_{5} \mathrm{O}$. is exothermic by $65 \mathrm{~kJ} \mathrm{~mol}^{-1}$ |14]; the sum of this energy plus any internal energy of nondissociating $\mathrm{C}_{2} \mathrm{H}_{5} \mathrm{OH}^{+}$. deposited upon electron impact $(\leq 26 \mathrm{~kJ}$ mol ${ }^{-1}$ ) defines the maximum initial energy content of $\mathrm{C}_{2} \mathrm{H}_{5} \mathrm{OH}_{2}^{+}$( $\leq 91 \mathrm{~kJ} \mathrm{~mol}^{-1}$ ). ${ }^{*}$ This also is the upper limit of the barrier for $\mathbf{1}^{+} \rightarrow 2^{+}$and compares favorably with one calculated value $\left(95 \mathrm{~kJ} \mathrm{~mol}^{-1}\right.$ [8a]), but less favorably with the other $\left(120 \mathrm{~kJ} \mathrm{~mol}^{-1}[8 \mathrm{~b}]\right)$.

According to theory [8], ion $1^{+}$is substantially more stable than $2^{+}$, so that equilibration between these two forms with energies above the isomerization barrier should greatly favor $1^{+}$. Nevertheless, $2^{+}$

\footnotetext{
*The upper limit of the internal energy of $\mathrm{C}_{2} \mathrm{H}_{5} \mathrm{OH}^{+}$. is $26 \mathrm{~kJ}$ $\mathrm{mol}^{-1}$, the dissociation threshold to $\mathrm{CH}_{3} \mathrm{CH}^{+} \mathrm{OH}+\cdot \mathrm{H}[14]$.
} 


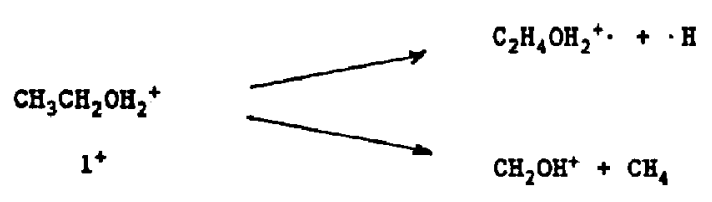

(no $\mathrm{H}$ встаmbling)

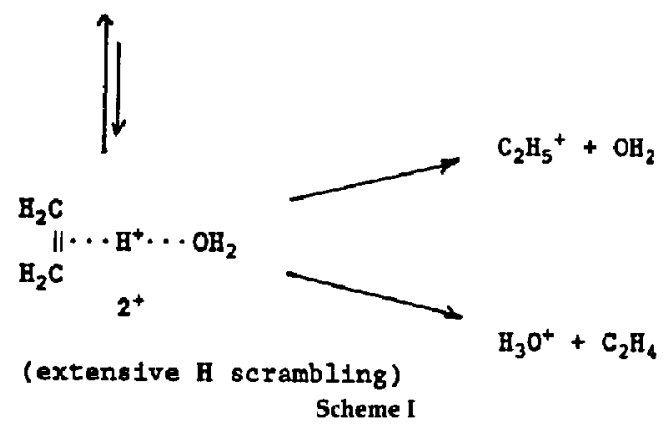

can coexist with $\mathbf{1}^{+}$if its internal energy is dissipated by collisions in the ion source, so that the thermodynamically favored reverse rearrangement $2^{+} \rightarrow 1^{+}$ (which requires at least $42 \mathrm{~kJ} \mathrm{~mol}^{-1}$ critical energy [8]) becomes impossible. In fact, under collision-free conditions the isomerization $\mathbf{1}^{+} \rightarrow \mathbf{2}^{+}$is not observed (see below).

Additional evidence for the coexistence of structures $1^{+}$and $2^{+}$is provided by the NR spectra (Figure 1 , right column). Neutralization of the classical ion $1^{+}$ produces a hypervalent radical which should dissociate at the hypervalent center [9], generating mainly $\mathrm{CH}_{3} \mathrm{CH}_{2} \mathrm{OH}+\cdot$ II and $\mathrm{C}_{2} \mathrm{II}_{5} \cdot+\mathrm{OH}_{2}$. Neutralization of $2^{+}$, on the other hand, should lead to a mixture of $\mathrm{C}_{2} \mathrm{H}_{4}, \cdot \mathrm{H}$, and $\mathrm{OH}_{2}$. The major dissociation products consistent with the NR spectra are ethanol (leading after reionization to its characteristic $\alpha$-cleavage fragments $\mathrm{CH}_{2} \mathrm{OH}^{+}$at $m / z \quad 31$ and $\mathrm{CH}_{3} \mathrm{CH}^{+} \mathrm{OH}$ at $\left.m / z 45\right)$, ethylene $(m / z 24-28)$, and water $(m / z 18)$. Ethanol originates from ion $1^{+}$in which the $\mathrm{H}$ atoms retain their positional identity; however, ethylene and water are formed with their $\mathbf{H}$ atoms scrambled (Figure 1), clear evidence that ion $2^{+}$ is present at neutralization because $1^{+}$(or 1 ) should not form scrambled ethylene.

Table 1. Reaction enthalpies

\begin{tabular}{|c|c|}
\hline & $\Delta \mathrm{H}\left(\mathrm{kJ} \mathrm{mol}^{-1}\right)$ \\
\hline $\mathrm{C}_{2} \mathrm{H}_{5} \mathrm{OH}_{2}^{+} \rightarrow \mathrm{CH}_{2} \mathrm{OH}^{+}+\mathrm{CH}_{4}$ & 121 \\
\hline $\mathrm{H}_{3} \mathrm{O}^{+}+\mathrm{C}_{2} \mathrm{H}_{4}$ & 136 \\
\hline $\mathrm{C}_{2} \mathrm{H}_{5}^{+}+\mathrm{OH}_{2}$ & 153 \\
\hline $\mathrm{C}_{2} \mathrm{H}_{4} \mathrm{OH}_{2}^{+} \cdot+\cdot \mathrm{H}$ & 443 \\
\hline $\mathrm{CH}_{2} \mathrm{OH}_{2}^{+} \cdot+\cdot \mathrm{CH}_{3}$ & 447 \\
\hline
\end{tabular}

See ref. 14
Although water and ethylene can also be formed by simple CAD of $2^{+}$, cogenerated with $\mathrm{C}_{2} \mathrm{H}_{5}^{+}$and $\mathrm{H}_{3} \mathrm{O}^{+}$(Scheme I), this accounts for only a minor amount of $\mathrm{H}_{2} \mathrm{O}^{+}$, and $\mathrm{C}_{2} \mathrm{H}_{4}^{+}$. formed by $\mathrm{NR}$. With $\mathrm{Hg}$ targets the CAD fragment ion yield is only $0.2 \%$, coproducing $0.2 \%$ neutrals. However, the total yield of neutrals is $2.5 \%$, indicating that most neutral products are formed after charge exchange. Furthermore, the absolute abundances of $\mathrm{H}_{2} \mathrm{O}^{+} \cdot$ and $\mathrm{C}_{2} \mathrm{H}_{4}^{+}$. decrease to $<<20 \%$ if $\mathrm{Hg}$ is replaced by $\mathrm{He}$, which mainly dissociates parent ions instead of neutralizing them [15]. The CAD and NR spectra of the isomeric protonated dimethyl ether are distinctively different from the spectra of Figure 1, indicating that this ion does not interconvert easily to either $1^{+}$or $2^{+}[4,10]$.

Low ion source pressure. Inder low ion source pressure conditions in which the newly formed $\mathrm{C}_{2} \mathrm{H}_{7} \mathrm{O}^{+}$ ions are not thermalized, and thus have higher internal energies, the $\mathrm{CAD}$ abundances of $\mathrm{H}_{3} \mathrm{O}^{+}$and $\mathrm{C}_{2} \mathrm{H}_{5}^{+}$decrease substantially (Figure 2), consistent with the abundance variability with change in internal energy for low energy CAD products (those dominant in the metastable ion spectrum) [4a]. The fragment ions from $\mathrm{H} \cdot$ and $\mathrm{CH}_{3}$ - loss become more abundant;

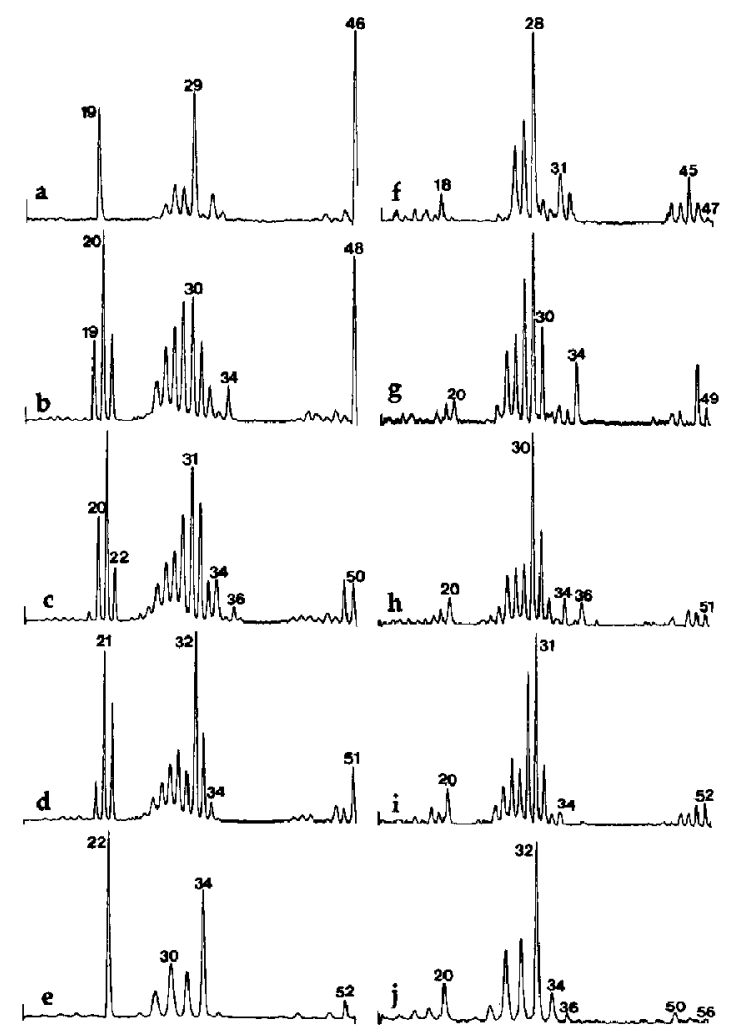

Figure 2. (a-e) CAD and $(\mathbf{f}-\mathbf{i})$ NR spectra of $(\mathbf{a}, \mathbf{f})$ $\mathrm{CH}_{3} \mathrm{CH}_{2} \mathrm{OH}_{2}^{+}$, (b, g) $\mathrm{CH}_{3} \mathrm{CH}_{2} \mathrm{OD}_{2}^{+}$, (c, h) $\mathrm{CH}_{3} \mathrm{CD}_{2} \mathrm{OD}_{2}^{+}$, (d, i) $\mathrm{CD}_{3} \mathrm{CH}_{2} \mathrm{OD}_{2}^{+}$, and $(e, j) \mathrm{CD}_{3} \mathrm{CD}_{2} \mathrm{OD}_{2}^{+}$under low ion source pressure conditions. 
both are formed without noticeable $H$ scrambling, indicating that they proceed from the initial classical structure $1^{+}$; their formation involves loss of a hydrogen from the original methyl or methylene (but not hydroxyl) groups and loss of the original methyl group, respectively. These same fragmentation processes are observed in the NR mass spectra, but these spectra also show a dramatic new feature.

\section{$\mathrm{C}_{2} \mathrm{H}_{7} \mathrm{O} \cdot$ Neutrals}

The NR mass spectra indicate that the counterneutral is much more stable when formed from these high energy $\mathrm{C}_{2} \mathrm{H}_{7} \mathrm{O}^{+}$ions (Figure 2, right column), leading to a sizable recovered parent ion $(\mathrm{m} / \mathrm{z} 47$ for $\left.\mathrm{C}_{2} \mathrm{H}_{7} \mathrm{O}^{+}\right)$. The contribution of the isobaric ${ }^{13} \mathrm{C}^{\mathrm{I2}} \mathrm{CH}_{6} \mathrm{O}^{+}$. in the NR spectrum of $\mathrm{C}_{2} \mathrm{H}_{5} \mathrm{OH}_{2}^{+}$is $<30 \%$ and the contribution of $\mathrm{C}_{2} \mathrm{H}_{6}^{18} \mathrm{O}^{+}$. in the NR spectrum of $\mathrm{C}_{2} \mathrm{H}_{5} \mathrm{OD}_{2}^{+}$is $<<10 \%$, so that the recovered parent ions mainly arise by reionization of hypervalent $\mathrm{C}_{2} \mathrm{H}_{7} \mathrm{O} \cdot$ that survived intact.

As found for other hypervalent neutrals [9], 1 neutrals exhibit relatively high stability for the $-\mathrm{OD}_{2}^{+}$isomers; reionized abundances (relative to that of the precursor ion, $\times 10^{-7}$ ) are $\mathrm{C}_{2} \mathrm{H}_{5} \mathrm{OH}_{2}, 7$; $\mathrm{C}_{2} \mathrm{D}_{5} \mathrm{OD}_{2} \cdot, 10 ; \mathrm{CD}_{3} \mathrm{CH}_{2} \mathrm{OD}_{2} \cdot, 60 ; \mathrm{CH}_{3} \mathrm{CD}_{2} \mathrm{OD}_{2}$, 70; and $\mathrm{C}_{2} \mathrm{H}_{5} \mathrm{OD}_{2}, 90$. Surprisingly, the perdeutero isomer shows an isotope effect similar to that of $\mathrm{C}_{2} \mathrm{H}_{5} \mathrm{OH}_{2} \cdot$. Upon reionization the surviving species loses $\mathrm{CH}_{3} \cdot$ and $\mathrm{H} \cdot$ without measurable $\mathrm{H}$ exchange, consistent with the classical structure $1 . \dagger$ The absence of appreciable $\mathrm{H}_{3} \mathrm{O}^{+}$and $\mathrm{C}_{2} \mathrm{H}_{5}^{+}$fragments after $\mathrm{NR}$ is also consistent with the lack of surviving $\mathrm{C}_{2} \mathrm{H}_{7} \mathrm{O}$. radicals of structure 2 , and that $\mathbf{1} \rightarrow \mathbf{2}$ does not take place after reionization due to insulficient energy for isomerization or/and lack of stabilizing collisions (see above). The surprising increase in $\mathrm{CH}_{3} \mathrm{CH}_{2} \mathrm{OH}_{2}$. stability when formed from excited $1^{+}$ions could arise from a more favorable Franck-Condon factor; the $\mathrm{C}-\mathrm{O}$ bond distance of ground state 1 should be much longer than that of the corresponding $1^{+}$ion, so that vibrational excitation is necessary to produce ground state 1 upon vertical neutralization, paralleling the behavior of $\mathrm{ND}_{4} \cdot, \mathrm{OD}_{3} \cdot$, and $\mathrm{CH}_{3} \mathrm{OH}_{2} \cdot$ [9]. This could also account in part for the isotope effect lowering $\mathrm{D}$ - loss from $\mathrm{C}_{2} \mathrm{H}_{5} \mathrm{OD}_{2}$ ' versus $\mathrm{H} \cdot$ loss from $\mathrm{C}_{2} \mathrm{H}_{5} \mathrm{OH}_{2} \cdot$. The sources of the additional observed isotope effects, especially those leading to the instability of $\mathrm{C}_{2} \mathrm{D}_{5} \mathrm{OD}_{2} \cdot$, are harder to discern. A possible explanation is that the $\mathrm{C}_{2} \mathrm{D}_{7} \mathrm{O}^{+}$ions contain a much higher proportion of isomer $2^{+}$, which produces an unstable counterneutral. Indeed, in the CAD and NR

$+\mathrm{CH}_{3}$ - and methylene-H - (or methyl-H - ) eliminations from neutral $\mathrm{C}_{3} \mathrm{CH}_{2} \mathrm{OH}_{2}$. would produce energy-rich ylides and are therefore extreniely improbable. For exanple, $\Delta \mathrm{H}\left(\mathrm{CH}_{3} \cdot+\mathrm{CI}_{2} \mathrm{OI} \mathrm{I}_{2}^{-}\right)$ $=+295 \mathrm{~kJ} \mathrm{~mol}-1$ compared to values of -124 and -17 for $\mathrm{CH}_{3} \mathrm{CH}_{2}-+\mathrm{OH}_{2}$ and $\mathrm{CH}_{3} \mathrm{CH}_{2} \mathrm{OII}+\cdot \mathrm{H}$, respectively $[14,16]$. Furthermore, $\mathrm{CH}_{2} \mathrm{OH}_{2}$ ' reionization yields intense $\mathrm{CH}_{x} \mathrm{O}^{+}$fragments $(x=1-3)$ [17], which are not observed in the NR spectra of Figure 2, spectra of the perdeutero sample, the losses of $D$. and $\mathrm{CD}_{3} \cdot$ which are diagnostic for structure $\mathbf{1}^{+}$are significantly lower than the analogous losses in the spectra of the other isomers (Figure 2).

\section{Conclusions}

Ion-neutral complexes play an important role in gasphase ion chemistry [18]. This study demonstrates that NR experiments can provide critical information on whether such species are just transition states for isotopic exchange or are bound structures with finite isomerization and dissociation barriers. Consistent with independent theoretical calculations [8], we find the proton-bound complex $2^{+}$to represent a stable isomer of the conventional protonated ethanol ion, 1 '.

For the $\mathrm{C}_{2} \mathrm{H}_{7} \mathrm{O} \cdot$ counterneutrals, only the classical structure 1 represents an energy minimum. Its structural geometry must be distorted from that of $1^{+}$to account for the unusual observation that stable $\mathbf{1}$ is only formed from excited $\mathbf{1}^{+}$.

\section{Acknowledgments}

We are grateful to M. J. Polce, M.-Y. Zhang, F. Turecek, and D. E. Drinkwater for assistance and helpful discussions, to L. Radom for a preprint of ref. 8a, to the National Science Foundation (grants CHE-8712039 and CHE-9014883) for generous financial support, and to the National Institutes of Health (grant GM16609) for partial instrument funding.

\section{References}

1. Dawson, P. H. Int. J. Mass Spectrom. Ion Phys. 1983, 50, 287-297.

2. Meot-ner (Mautner), M.; Ross, M. M.; Campana, J. E. J. Am. Chem. Soc. 1985, 107, 4839-4845, Mautner, M.; Sieck, L. W. Int. I. Mass Spectrom. Ion Processes 1989, 92, 123-133.

3. Harrison, A. G. Org. Mass Spectram. 1987, 22, 637-641.

4. (a) Jarrold, M. F.; Kirchner, N. J.; Liu, S.; Bowers, M. T. J. Phys. Chem. 1986, 90, 78-83. (b) Jarrold, M. F.; Illies, A. I.; Kirchner, N. J.; Bowers, M. T. Org. Mass Spectrom. 1988, 18, 388-395.

5. Smith, S. C.; McEwen, M. J.; Giles, K.; Smith, D.; Adams, N. G. Int.l J. Mass Spectrom. Ion Processes 1990, 96, 77-96.

6. McLafferty, F. W.; Bente, P. F. III; Kornfeld, R.; Tsai, S.-C.; Howe, I. J. Am. Chem. Soc. 1973, 95, 2120-2129. Zwinselman, J. J.; Nibbering, N. M. M.; Ciommer, B.; Schwarz, H. In Tandem Mass Spectrometry; McLafferty, F. W., Ed.; Wiley: New York, 1983; pp 67-104.

7. Wesdemiotis, C.; McLafferty, F. W. Chem. Rev. 1987, 87, 485-500. Terlouw, J. K.; Schwarz, H. Angew. Chem. Int. Ed. Engl. 1987, 26, 805-815. Holmes, J. L. Mass Spectrom. Rev. 1988, 8, 513-539. McLafferty, F. W. Science (Washington, D.C.) $1990,247,925-929$.

8. (a) Swanton, D. J.; Marsden, B. C. J.; Radom, L. Org. Mass Spectrom., in press. (b) Bouchoux, G.; Hoppilliard, Y. J. Am. Chem. Soc. 1990, 172, 9110-9115.

9. Gellene, G. I.; Porter, R. F. Acc. Chem. Res. 1983, 16, 200-207. Raksit, A. B.; Porter, R. F. Int. J. Mass Spectrom. Ion Processes 1987, 76, 299-306; Raksit, A. B.; Porter, R. F. 
Org. Mass Spectrom. 1987, 22, 410-417. Wesdemiotis, C.; Feng, R.; McLafferty, F. W. J. Am. Chem. Soc. 1986, 108, $5656-5657$.

10. Holmes, J. L.; Sirois, M. Org. Mass Spectrom. 1990, 25, 481-482.

11. Feng, R.; Wesdemiotis, C.; Baldwin, M. A.; McLafferty, F. W. Int. J. Mass Spectrom. Ion Processes 1988, 86, 96-107.

12. Wesdemiotis, C.; McLafferty, F. W. Org. Mass Spectrom. 1989, 24, 663-668.

13. Todd, P. J.; McLafferty, F. W. Int. J. Mass Spectrom. Ion Phys. 1981, 38, 371-378.
14. Lias, S. G.; Bartmess, J. E.; Liebman, J, F.; Holmes, J. L.; Levin, R. D.; Mallard, W. G. J. Phys. Chem. Ref. Data 1988, 17, Suppl. No. 1. Lias, S. G.; Liebman, J. F.; Levin, R. D. I. Phys. Chem. Ref. Data 1984, 13, 695-808.

15. Danis, P. O.; Feng, R.; McLafferty, F. W. Anal. Chem. 1986, $58,348-354$.

16. Yates, B. F.; Bouma, W. J.; Radom, L. I. Am. Chem. Soc. $1987,109,2250-2263$.

17. Wesdemiotis, C.; Feng, R, Danis, P. O.; Williams, E. R.; McLafferty, F. W. J. Am. Chem. Soc. 1986, 108, 5847-5853.

18. McAdoo, D. J. Mass Spectrom. Rev. 1988, 7, 363-393. 